\title{
Możliwości budowania spersonalizowanej przestrzeni edukacyjnej dla wspierania rozwoju dzieci w wieku wczesnoszkolnym
}

\author{
The Possibility of Building \\ a Personalised Learning Space \\ to Support the Development of Children \\ at Early School Age
}

\begin{abstract}
ABSTRAKT
Współczesne środowisko edukacyjne, na skutek dynamicznego rozwoju nowych technologii informacyino-komunikacyinych, posiada w coraz większym stopniu charakter spersonalizowany. Przyczynia się do tego z jednej strony specyfika nowych mediów cyfrowych i możliwość tworzenia wirtualnej przestrzeni, w której ma miejsce proces uczenia się i nauczania, a z drugiej - obecne tendencje w podejściu do procesu kształcenia. Wskazuja one na konieczność dostosowania procesu nauczania, w znacznie większym niż dotychczas zakresie, do konkretnych potrzeb ucznia. Kładzie się również nacisk na podmiotowość ucznia i jego samodzielność w podejmowaniu
\end{abstract}

StOWA KLUCZOWE spersonalizowana przestrzeń edukacyina, środowisko edukacyine, wspieranie rozwoju dziecka w wieku wczesnoszkolnym, środowisko wirtualne, technologie informacyino-komunikacyjne

KEYWORDS

personal learning environment, learning space, supporting the development of a child in early school age, virtual environment, information and communication technologies

SPI Vol. 20, 2017/3

ISSN 2450-5358

e-ISSN 2450-5366 DOI: 10.12775/SPI.2017.3.005

Artykuły i rozprawy 
aktywności edukacyjnych. W kontekście tych zjawisk ważnym elementem procesu dydaktycznego wydaje się być projektowanie środowiska dydaktycznego uwzględniajqcego działania indywidualizacyjne.

Przedmiotem niniejszego opracowania uczyniono refleksję nad spersonalizowanq i dostosowanq do możliwości rozwojowych dziecka przestrzeniq edukacyinq. Natomiast celem jest opisanie możliwości budowania takiej spersonalizowanej przestrzeni edukacyinej dla wspierania rozwoju ucznia, zarówno w kontekście teoretycznym, jak i w wymiarze praktycznym. W prowadzonych rozważaniach skoncentrowano się przede wszystkim na potrzebach dzieci w wieku wczesnoszkolnym. Zwrócono uwagę, że nauczanie dostosowane do indywidualnych preferencji każdego ucznia jest możliwe w grupie dzieci o zróżnicowanych możliwościach intelektualnych. Jest to zadanie, któremu powinien sprostać każdy nauczyciel edukacji wczesnoszkolnej, rozpatrujqc je nie w kategorii trudności, ale wyzwania. Ponadto wskazano na pewne typy zasobów i narzędzi internetowych, które moga być użyteczne dla działań edukacyinych, z punktu widzenia indywidualizacji kształcenia.

\section{ABSTRACT}

As a result of the dynamic development of new information and communication technologies, today's educational environment has becoming increasingly personalized. On the one hand, it contributes to the specificity of the new digital media and the ability to create a virtual space in which to place the process of learning and teaching, and the other to the current trends in the approach to the learning process. These trends indicate the need to adapt the process of learning to the specific needs of the student to a much larger extent than to date. They put the emphasis on student-centered learning and independence in undertaking educational activities. In the context of these phenomena, an important part of the educational process seems to consider personalizing actions when designing the educational environment.

The object of this study was a personalized educational space, adapted to the possibilities of child development. The goal study was to describe the possibility of constructing such a personalized learning space to support student development, both in theory and in a practical context. In these considerations the authors focused primarily on the needs of children at early school age. It was pointed out that the teaching tailored to the individual preferences of each student is possible for children with different intellectual abilities. It is a task which should be 
met by every teacher of early childhood education, considering it not as a problems but rather a challenge. Moreover, some types of resources and online tools were identified which can be useful for educational activities from the point of view of individual pupils.

\section{Wprowadzenie}

Współczesne trendy w edukacji wskazują na rosnące znaczenie zindywidualizowanego procesu uczenia i nauczania oraz potrzebę tworzenia dla niego odpowiedniej przestrzeni. Centralnym punktem działań edukacyjnych ze strony instytucji oświatowych, nauczycieli i wychowawców staje się dziecko ze swoimi osobistymi potrzebami rozwojowymi w sferze poznawczej, społecznej i fizycznej. Proces uczenia się w szerokim ujęciu stanowi bowiem podstawę wszelkiej aktywności życiowej człowieka. Zmieniające się dynamicznie warunki środowiskowe, szczególnie postęp w zakresie nowych technologii, wymuszają potrzebę wdrażania do edukacji ustawicznej, związanej z koniecznością ciągłego poszerzania swojej wiedzy i umiejętności.

Jednym z podstawowych zadań szkoły i całego systemu oświatowego staje się zatem przygotowanie młodego człowieka do samokształcenia, przejęcia odpowiedzialności za własny proces kształcenia. Nauczyciele i rodzice, chcąc formować u dziecka świadome i aktywne postawy wobec procesu uczenia, powinni pomagać mu w tworzeniu takiej osobistej przestrzeni informacyjnej i edukacyjnej, która byłaby dostosowana do jego specyficznych wymagań i preferencji. Mając na uwadze znaczenie jakie ma personalizacja dla efektywności całego procesu kształcenia, autorki za cel tego opracowania obrały ukazanie możliwości budowania takiego środowiska edukacyjnego, w którym dzieci w wieku wczesnoszkolnym mogłyby rozwijać swoje indywidualne zainteresowania i talenty oraz znaleźć inspiracje i motywacje do dalszego rozwoju.

\section{Tworzenie spersonalizowanej przestrzeni edukacyjnej}

Pojęcie przestrzeni edukacyjnej jest terminem wieloznacznym. W podstawowym zakresie odnoszone bywa do fizycznego otoczenia, określonej materialnej rzeczywistości, która nas otacza i w której ma 
miejsce proces kształcenia. Aleksander Nalaskowski opisując przestrzenie szkoły zaznacza, że można ją rozpatrywać również w dużo szerszym kontekście, np. społecznym, publicznym czy bardzo wąskim, kiedy mamy na myśli przestrzeń prywatną czy intymną. Dokonany przez niego przegląd różnorodnych podejść obecnych w rozważaniach o przestrzeni ujawnia, że w jej ramach analizowane są nie tylko obiekty fizyczne (budowle, sale, przedmioty), ale również różne stany, takie jak zespoły zachowań, nawyki, emocje itp ${ }^{1}$.

Podobnie Barbara Dudel i Małgorzata Głoskowska-Sołdatow szczegółowo analizując możliwe interpretacje przestrzeni edukacyjnej, poza tradycyjnym jej rozumieniem jako sfery czysto materialnej $i$ instytucjonalnej, wskazują na częste

rozumienie jej [przestrzeni edukacyjnej - przyp. aut.] jako pola d z i a n i a si ę edukacyjnego, splotu najróżniejszych sytuacji dydaktycznych i wychowawczych, okazji do uczenia się i nauczania, niczym nieograniczone działania ucznia i wokół ucznia, pozwalające mu na gromadzenie doświadczeń, negocjowanie znaczeń i na budowanie własnej wiedzy².

Obszary znaczeniowe terminów przestrzeń edukacyjna i środowisko edukacyjne przenikają się wzajemnie. Samo pojęcie środowiska interpretowane bywa jako „system stosunków zachodzących między osobą żywą a otaczającymi ją przedmiotami”’ $\mathrm{Z}$ kolei środowisko edukacyjne to otoczenie, w którym dokonuje się proces nauczania i uczenia się, a składają się na nie zarówno elementy środowiska fizycznego, społecznego, jak i kulturalnego ${ }^{4}$.

Od kilkunastu lat, szczególnie w literaturze anglojęzycznej podejmującej problematykę procesu uczenia się, zaczął upowszechniać się termin personal learning environment (PLE). Pojawił się on przede wszystkim w kontekście adaptacji nowych cyfrowych technologii do budowania indywidualnej przestrzeni kształcenia. Powstał jako pewna analogia do pojęcia virtual learning environment, które bardziej uwypuklało aspekt projektowania środowiska $\mathrm{z}$ punktu widzenia

1 A. Nalaskowski, Przestrzenie i miejsca szkoty, Kraków 2002, s. 15.

2 B. Dudel, M. Głoskowska-Sołdatow, Wspótczesna przestrzeń edukacyjna uczniów klas mtodszych, w: Wielowymiarowość przestrzeni życia wspótczesnego dziecka, red. J. Izdebska, J. Szymanowska, Białystok 2009, s. 171-182.

3 S. Juszczyk, Dydaktyka informatyki i technologii informacyjnej, Torun 2006, s. 335.

4 Tamże. 
nauczyciela niż ucznia. Idea PLE bazuje na koncepcji bezpośredniego zaangażowania ucznia, tworzenia przez niego wielowymiarowej i elastycznej przestrzeni, która ma na celu wspomaganie indywidualnego procesu uczenia się, z uwzględnieniem osobistych celów edukacyjnych. Ponadto jest to przestrzeń, w której różne rodzaje technologii i usług sieciowych wykorzystywane są w zarządzaniu zasobami i materiałami dydaktycznymi, ułatwiają sprawowanie kontroli nad przebiegiem procesu kształcenia i umożliwiają komunikację z innymi uczestnikami procesu edukacyjnego. Takie środowisko w mniej lub bardziej świadomy sposób tworzy każdy uczeń indywidualnie, dostosowując je do swoich bieżących potrzeb, preferencji i dotychczasowych doświadczeń ${ }^{5}$. Koncepcja PLE odnosi się bardziej do edukacji nieformalnej niż do działań zinstytucjonalizowanych. Chodzi w niej o stworzenie środowiska uczenia się, które pomagałoby uczniowi w kontrolowaniu i kierowaniu osobistym procesem uczenia się ${ }^{6}$.

Budowanie takiej indywidualnej przestrzeni wymaga od ucznia pewnej dojrzałości i samoświadomości w zakresie potrzeb edukacyjnych. Pojawia się zatem pytanie czy uczniowie w młodszym wieku szkolnym są w stanie stać się kreatorami takiego środowiska? Wydaje się, że zastąpić je mogą w tej roli rodzice i nauczyciele, którzy powoli i systematycznie powinni wdrażać dziecko do planowania swojej aktywności edukacyjnej i wytyczania własnych celów. Ważny czynnik stanowi również wsparcie $\mathrm{w}$ trakcie realizowania postawionych zadań. Rodzice dobrze znający potrzeby dziecka, we współpracy z nauczycielem są w stanie tworzyć otoczenie, które inspiruje i stymuluje aktywność edukacyjną dziecka, ułatwiając mu eksplorację zasobów edukacyjnych, w tym pozyskiwanie i porządkowanie informacji oraz budowanie na ich podstawie wiedzy.

Philip E. Banyad i Jean Underwood mając na uwadze, że proces uczenia ma miejsce w bardzo różnych kontekstach i sytuacjach

5 Zob.: Personal Learning Environments. NMC Horizon Report: 2012 K-12 Edition, <http://www.nmc.org/pdf/2012-horizon-k12-ple.pdf> oraz Personal Learning Environments, <http://horizon.wiki.nmc.org/Personal+Learning+Environments> [dostęp: 4.10.2016].

6 I. Pulak, Projektowanie spersonalizowanego środowiska ksztatcenia jako element information literacy, „Bibliotheca Nostra. Śląski Kwartalnik Naukowy” 2012, nr 2 (28), s. 87-99, <http://www.sbc.org.pl/dlibra/docmetadata?id=61361\&f rom=publication $>$ [dostęp: 4.10.2016]. 
umiejscawiają indywidualne środowisko edukacyjne właśnie na styku tej oficjalnej przestrzeni szkolnej, jak i tej domowej, osobistej, nieujętej w oficjalne, instytucjonalne ramy ${ }^{7}$. Rozmaitość i bogactwo takiego środowiska edukacyjnego sprzyja kształceniu wielostronnemu i przekłada się również na jakość całego procesu kształcenia.

Istotną rolę we wdrażaniu dziecka do samodzielnej pracy, budzeniu i wspieraniu indywidualnych motywacji, odgrywają także nauczyciele. Poprzez działania indywidualizacyjne, dostosowanie treści, metod i form kształcenia do potrzeb i możliwości pojedynczych uczniów są w stanie tworzyć unikatowe i spersonalizowane środowiska edukacyjne.

\section{Możliwości indywidualizacii nauczania w edukacii wczesnoszkolnej}

Termin indywidualizacja nauczania może być rozpatrywany w szerokim kontekście i różnorodnie rozumiany. Tradycyjnie oznacza „[... [ uwzględnienie w systemie dydaktyczno-wychowawczym różnic w rozwoju poszczególnych uczniów oraz dostosowanie treści, metod i organizacji działań pedagogicznych do tych różnic". W literaturze możemy znaleźć inne określenia, np. dostosowanie wymagań do możliwości wychowanków, indywidualne podejście do dziecka czy liczenie się $\mathrm{z}$ ogólnym stanem rozwoju jednostki. Zwrócenie uwagi na różnice rozwojowe dzieci rozpoczynających naukę w szkole to efekt stale poszerzającej się wiedzy na temat właściwości i sposobów funkcjonowania ludzkiego intelektu. Liczne badania dowodzą, że dzieci nie zawsze rozwijają się w sposób harmonijny i jednostajny, a poszczególne cykle rozwoju przeplatane są fazami regresu i progresu. Indywidualne różnice między dziećmi zauważalne są już na etapie przedszkola, a tym bardziej będą obserwowalne na poziomie edukacji wczesnoszkolnej. Różnice te mogą dotyczyć:

- zasobu wiedzy, umiejętności oraz doświadczeń życiowych;

- przebiegu procesów poznawczych;

- sposobów motywacji do uczenia się (w tym preferencji w zakresie sposobów zdobywania wiedzy i umiejętności);

7 P.E. Banyard, J. Underwood, Understanding the Learning Space (4.07.2008). Elearningpapers, <https://dialnet.unirioja.es/servlet/articulo?codigo=2937422> [dostęp: 7.10.2016].

8 C. Kupisiewicz, M. Kupisiewicz, Stownik pedagogiczny, Warszawa 2009, s. 65. 
- zainteresowań, zdolności ogólnych i uzdolnień specjalnych;

- możliwości fizycznych, a także dyspozycji emocjonalno-społecznych;

- warunków środowiskowych, w których żyje dziecko.

Wyżej wymienione grupy czynników wskazują, że każde dziecko wymaga indywidualnego podejścia, także $\mathrm{w}$ procesie nauczania, co znalazło swoje odzwierciedlenie w dokumentach prawnych regulujących oświatę w Polsce. W Podstawie programowej kształcenia ogólnego dla szkół podstawowych możemy odnaleźć następujące stwierdzenie: „Szkoła oraz poszczególni nauczyciele podejmują działania mające na celu zindywidualizowane wspomaganie rozwoju każdego ucznia, stosownie do jego potrzeb i możliwości”'. Zapis ten z jednej strony niejako wymusza na każdym nauczycielu obowiązek dostosowania sposobu nauczania dzieci $\mathrm{w}$ wieku wczesnoszkolnym do ich predyspozycji rozwojowych, a z drugiej - zwraca uwagę na różnorodność uczniów i ich potrzeb edukacyjnych, rozmaitość trudności wynikających $z$ indywidualnego tempa rozwoju, mnogość potencjałów i możliwości tkwiących w każdym dziecku. Warto zatem zadbać, aby każdy uczeń zdobywał wiedzę i umiejętności na miarę własnych zdolności, w różnorodny sposób, ponieważ stanowi niepowtarzalne indywiduum. Nie da się „wypośrodkować” dziecięcej wiedzy ani umysłu, trudno też podać jeden, najwłaściwszy szablon kształcenia młodego pokolenia.

Znaczenie nauczania opartego na zasadach indywidualizacji widzi się w jego ścisłym powiązaniu z metodyką edukacji wczesnoszkolnej. W klasach I-III nie ma przyzwolenia na drugoroczność, nie zachodzi też zjawisko niepowodzenia dydaktycznego ${ }^{10}$. Konsekwencją tego założenia jest opisowa ocena osiągnięć ucznia, obrazująca poziom rozwoju danego dziecka. Stanowi ona element oceniania ksztaltującego, w którym nie tylko rodzic, ale przede wszystkim uczeń, otrzymuje informację jaką wiedzę i umiejętności już opanował, a nad czym musi jeszcze pracować. Taka forma informacji zwrotnej nie jest podsumowaniem procesu uczenia się, ale służy jego wspomaganiu w celu zachęcenia uczniów do podejmowania samodzielnego wysiłku edukacyjnego.

9 Podstawa programowa kształcenia ogólnego dla szkół podstawowych, Dz.U. 2016, poz. 895, Załącznik nr 2, s. 10.

10 J. Kamińska, Ocenianie osiagnięć uczniów w edukacji wczesnoszkolnej, Gdańsk 2000 . 
Rozważania nad indywidualizacją w nauczaniu nie są czymś nowym, a samo zagadnienie posiada bogatą literaturę. Istnieją jednak rozbieżności w jej pojmowaniu, co obrazuje praktyka szkolna. Zdarza się bowiem, że o indywidualizacji mówi się w sytuacjach kiedy podczas zajęć uczniowie pojedynczo, indywidualnie rozwiązują te same zadania. Inne doświadczenia wskazują na realizację jej elementów, ale w sposób wybiórczy, ograniczający się np. do różnicowania kryteriów kontroli i oceny osiągnięć uczniów (od jednych dzieci wymaga się więcej, od innych zdecydowanie mniej). Przez indywidualizację nauczania rozumie się także sytuacje, w których nauczyciel, biorąc pod uwagę poziom osiągnięć uczniów, dzieli zespół klasowy na kilka stałych grup. Grupy te realizują podczas zajęć szkolnych zadania o zróżnicowanym stopniu trudności, a przy ocenianiu nauczyciel bierze pod uwage jakość wykonania zalecanych zadań. Indywidualizacja może też być postrzegana przez pryzmat zajęć wyrównawczych dla uczniów słabszych lub np. kółek zainteresowań rozszerzających materiał nauczania dla uczniów wykazujących uzdolnienia. Również indywidualne nauczanie orzekane przez poradnię psychologiczno-pedagogiczną na wniosek rodziców bywa utożsamiane z procesem indywidualizacji ${ }^{11}$. Wymienione wyżej przykłady pokazują, że rozumienie indywidualizacji nauczania jest albo błędne, albo realizowane fragmentarycznie, co wpływa hamująco na rozwój potencjału dziecka. Aby temu zjawisku przeciwdziałać, nauczyciel może podejść do indywidualizacji na co najmniej dwa sposoby. Pierwszy z nich, zdecydowanie trudniejszy, polega na opracowaniu dla każdego ucznia indywidualnych planów nauki, opartych na jednostkowych potrzebach, możliwościach i upodobaniach. $Z$ jednej strony pomysł ten wydaje się być trafny, ponieważ w pełni realizuje indywidualne podejście do każdego ucznia. Zadania wykonywanie przez dzieci, przy założeniu trafnej diagnozy, oscylowałyby w strefie ich najbliższego rozwoju. Jednak przez wielu nauczycieli jest on postrzegany jako utopijny i niemożliwy do realizacji w normalnej, liczącej wielu uczniów klasie. Drugie podejście to realizacja procesu edukacyjnego na zasadach nauczania zróżnicowanego. Nauczanie to umożliwia zastosowanie wielu

11 J. Rafał-Łuniewska, Indywidualizacja nauczania a edukacja wczesnoszkolna, s. 8-9, <https://www.ore.edu.pl/materiay-do-pobrania-41018/category/244-specyficzne-trudnoci-w-uczeniu-si?download=2846: indywidualizacja-nauczania-a-edukacja-wczesnoszkolna> [dostęp: 5.10.2016]. 
możliwości i alternatywnych rozwiązań, tak aby pozostawić dziecku wybór np. w zakresie stopnia trudności zadania, sposobu zdobywania wiedzy czy czasu opanowania danej umiejętności. W takim systemie nauczania dzieci same kontrolują swój proces kształcenia, stając się przy tym bardziej samodzielne, a rola nauczyciela sprowadza się do dyskretnej pomocy oraz zapewniania różnorodności podczas organizowania zajęć. Biorąc pod uwagę wyniki własnych obserwacji czy przeprowadzonych diagnoz, sięgając do opinii poradni psychologiczno-pedagogicznej czy innych orzeczeń zawierających wskazówki dotyczące sposobów pracy z uczniem, nauczyciel dostosowuje proces edukacyjny tak, aby sprzyjał on maksymalnemu rozwojowi wszystkich uczących się. Obszary tych dostosowań dotyczą: celów, treści, a także zasad, metod, form i środków dydaktycznych. Nauczanie dostosowane do indywidualnych preferencji każdego dziecka powinno również uwzględniać następujące grupy czynników:

1) Odpowiedni, pod względem stopnia trudności, dobór zadań i problemów do rozwiązania zarówno podczas edukacji szkolnej, jak i domowej.

2) Różnicowanie metod i form sprawdzania wiedzy i umiejętności uczniów, jasne kryteria oceniania. W edukacji wczesnoszkolnej zasadne jest stosowanie oceniania kształtującego ${ }^{12}$, które informuje ucznia o zakresie wiedzy i umiejętności podlegających kontroli nauczyciela, a także stopniu ich opanowania. Taki sposób oceniania eliminuje porównywanie się uczniów między sobą, a bardziej koncentruje się na docenieniu dziecięcych postępów edukacyjnych.

3) Adekwatna aranżacja przestrzeni edukacyjnej w zależności od sposobów pracy, np. inne ustawienie ławek podczas pracy z małymi grupami, a jeszcze inne w sytuacji prowadzenia zajęć $\mathrm{z}$ całym zespołem. Sposoby organizacji nauczania $\mathrm{w}$ klasie powinny też uwzględniać specyfikę możliwości rozwojowych dziecka, np. uczeń przejawiający zaburzenia ze spektrum nadpobudliwości psychoruchowej powinien zajmować pierwszą ławkę, blisko nauczyciela, raczej samodzielnie niż $\mathrm{w}$ towarzystwie innych dzieci $\mathrm{z}$ klasy.

4) Wypracowanie przez nauczyciela indywidualnego stylu pracy. Styl ten wiąże się nie tylko z różnicowaniem elementów procesu edukacyjnego, ale również z umiejętnością uważnej obserwacji każdego

12 D. Sterna, Ocenianie ksztattujące w praktyce, Warszawa 2006. 
dziecka, a także trafnej diagnozy. Dzięki takim działaniom możliwe jest $\mathrm{w}$ miarę wczesne wykrycie specyficznych trudności $\mathrm{w}$ uczeniu się, co ma istotne znaczenie $\mathrm{w}$ dalszej pracy z uczniem, i ewentualne objęcie go indywidualnym wsparciem psychologiczno-pedagogicznym. W postępowaniu ukierunkowanym na dostosowanie procesu edukacyjnego do możliwości każdego ucznia nauczyciel nie jest osamotniony. Priorytetowe znaczenie w tym działaniu ma współpraca z poradnią psychologiczno-pedagogiczną, a następnie stosowanie się do jej opinii.

5) Współpraca nauczyciela $z$ rodzicami dziecka. W realizacji indywidualnego nauczania dużym wsparciem, poza specjalistami, są rodzice ucznia, którzy znają go najlepiej i są w stanie szybciej dostrzec pewne zmiany w jego funkcjonowaniu. Bieżąca i systematyczna współpraca ma służyć jak najlepszemu zaspokojeniu indywidualnych, edukacyjnych potrzeb dziecka. Wspieranie rodziców dzieci ze specjalnymi potrzebami edukacyjnymi może przybierać formę porad, konsultacji, warsztatów czy szkoleń. Nastawione jest na rozwiązywanie problemów wychowawczych i dydaktycznych stwarzanych przez dziecko i powinno podnosić umiejętności wychowawcze samych rodziców, co z kolei wpływa korzystnie na efektywność indywidualnych oddziaływań nauczyciela ${ }^{13}$.

Uwzględnienie indywidualizacji w nauczaniu ma niebagatelne znaczenie dla rozwoju dziecka. Uczeń poddany procesowi edukacyjnemu, który bierze pod uwagę jego indywidualne predyspozycje, lepiej się rozwija, ma szanse odkryć własny potencjał, zwiększyć swoją aktywność i motywację do udziału w zajęciach proponowanych przez nauczyciela. Indywidualizacja, na której opiera się nauczanie zróżnicowane, ma również doniosłą wartość dla samego nauczyciela. Informuje go o postępach uczniów, umożliwia bieżącą ocenę efektów własnej pracy, przyczynia się do stałego poszerzania wiedzy oraz podnoszenia własnych kompetencji. Istotne jest, aby indywidualizacja nie była postrzegana przez nauczycieli jako trudność, ale jako wyzwanie dające możliwość rozwinięcia własnego potencjału. To okazja odejścia od skostniałej organizacji toku nauczania czy rutyny szkolnego życia na rzecz budowania pluralizmu komunikacyjnego i przyzwolenia na inność.

13 J. Rafal-Łuniewska, Indywidualizacja nauczania a edukacja wczesnoszkolna, dz. cyt., s. 29. 


\section{Internet i nowe media jako nowoczesne środowisko edukacyjne}

Internet jako baza zasobów edukacyjnych i przestrzeń komunikacyjna może pełnić bardzo wiele funkcji w procesie kształcenia, zarówno tym mającym miejsce $w$ ramach edukacji formalnej, organizowanej przez instytucje oświatowe, jak również w indywidualnym procesie uczenia się. Może również stanowić przedłużenie środowiska dydaktycznego na obszar cyberprzestrzeni.

$\mathrm{Z}$ punktu widzenia tworzenia takiego indywidualnego środowiska edukacyjnego w przestrzeni wirtualnej warto wyróżnić trzy główne jego elementy:

- zasoby informacyjne;

- materiały edukacyjne (w tym multimedialne i interaktywne);

- narzędzia komunikacji i pracy grupowej.

Pierwszy element związany jest $\mathrm{z}$ bogactwem informacji, które obecnie dostępne są za pośrednictwem sieci. Internet zaczyna przejmować funkcję jaką spełniały dotąd biblioteki szkolne i domowe, umożliwia bowiem korzystanie z szerokich zasobów informacyjnych, takich jak encyklopedie, słowniki, atlasy, leksykony czy czasopisma online. Uczeń wchodząc do sieci staje jednak w obliczu ogromu informacji. Nadmiar ten staje się równocześnie poważnym problemem. W przypadku młodych użytkowników Internetu istotną rolą opiekunów jest kształtowanie umiejętności selekcji, wyboru rzetelnych i adekwatnych źródeł, dostosowanych do wieku i stopnia rozwoju poznawczego dziecka. Rodzice i nauczyciele moga zatem podpowiadać i proponować dziecku wartościowe publikacje i materiały i strony, które może ono wykorzystać w procesie uczenia się i które łatwo może znaleźć w sieci. Pożądanym podejściem do wykorzystania zasobów Internetu w szeroko pojętym procesie edukacyjnym jest również traktowanie tych zasobów nie tyle jako gotowych informacji, ale raczej jako obszaru własnych poszukiwań i dociekań badawczych.

Personalizacja kształcenia polega na dostosowaniu treści metod i form kształcenia do indywidualnych preferencji i możliwości uczących się. Dzieje się to najczęściej poprzez wykorzystanie materiałów edukacyjnych, które uwzględniałyby potrzeby konkretnego ucznia. Zasoby edukacyjne Internetu mogą być w tym zakresie niezwykle pomocne. Ich zaletą jest nie tylko duża liczba, ale przede wszystkim różnorodność form przekazu. Składają się na nią materiały 
audiowizualne i interaktywne. Walorem multimedialnych materiałów edukacyjnych jest zaangażowanie wielu zmysłów i oddziaływanie na sferę emocjonalną. Szczególnie interesujące dla dziecka w młodszym wieku są materiały edukacyjne bazujące na elementach gier, kojarzone raczej z rozrywką, a nie $\mathrm{z}$ wymagającą wysiłku nauką. Silnemu zaangażowaniu ucznia sprzyjać może z jednej strony sama narracja gry, która wymusza stały poziom koncentracji, a z drugiej - wywołujący silne emocje element rywalizacji. W praktyce Internet może stanowić uzupełnienie tradycyjnego procesu kształcenia, dostarcza bowiem różnorodne materiały dydaktyczne, m.in. programy i prezentacje multimedialne, programy służące samokontroli, w tym testy, quizy, obudowy internetowe podręczników szkolnych itp.

Kolejnym elementem składowym indywidualnego środowiska edukacyjnego mogą być sieciowe narzędzia komunikacyjne, w tym portale społecznościowe, komunikatory internetowe, platformy edukacyjne czy dzienniki elektroniczne. Umożliwiają one systematyczny kontakt $\mathrm{z}$ nauczycielem i innymi uczniami. Ułatwiają tworzenie zespołów uczniowskich, które wspólnie realizują określone cele kształcenia, rozwijają swoje zainteresowania i poszerzają wiedzę. Obecnie jest dostępnych wiele bezpłatnych narzędzi do pracy grupowej, które wspierają komunikację i ułatwiają współpracę w sieci.

Coraz częściej również szkolna dydaktyka sięga po zasoby i usługi internetowe. Wśród nauczycieli upowszechniają się metody nauczania, które wymagają dostępu do sieci. Niosą one ze sobą nową jakość, związaną z możliwością różnicowania zarówno tempa nauki, jak i zakresu realizowanych treści. Takimi przykładami działań edukacyjnych, w których idea indywidualizacji jest realizowana w znacznym wymiarze, jest np. Metoda odwróconej klasy ${ }^{14}$ czy Akademia Khana ${ }^{15}$. Również edukacja domowa bazuje na tworzeniu takiej indywidualnej przestrzeni edukacyjnej dostosowanej do potrzeb konkretnego dziecka.

14 P. Peszko, Co to jest flipped classroom? Jak dziata odwrócona klasa?, <http:// blog.2edu.pl/2011/09/flipped-classroom-odwrocona-klasa-czyli.html> [dostęp: 11.10.2016].

15 Strategia wyprzedzająca tradycyjna lekcje, Edukacja. Internet. Dialog, <http:// edukacjaidialog.pl/news/strategia_wyprzedzajaca_tradycyjna_lekcje,1966. html> [dostęp: 10.10.2016]. 
Współcześnie praktycznie w każdym domu jest już stały dostęp do Internetu, szczególnie - jak pokazują statystyki - w gospodarstwach domowych, w których są dzieci. Znika więc bariera, która uniemożliwiała dotąd wykorzystanie na szeroką skalę do celów edukacyjnych potencjału tkwiącego $\mathrm{w}$ środowisku wirtualnym. Warto przy tym zauważyć, że idea budowania takich spersonalizowanych i otwartych przestrzeni, które wdrażają dziecko do samodzielnej pracy oraz budzą i wspierają indywidualne motywacje dziecka, nie jest nowa, obecnie mamy tylko do dyspozycji większe możliwości i efektywniejsze narzędzia.

\section{Zakończenie}

Podsumowując prezentowane rozważania i podkreślając wagę podejmowanych zagadnień, warto przytoczyć słowa Józefy Bałachowicz:

Dyskurs o edukacji dziecka trzeba więc wzbogacić o następujące wartości: wspieranie autonomii dziecka, rozwijanie sprawczości i zaangażowania, rozwijanie umiejętności pracy grupowej, tworzenia warunków do wrastania we wspólnotę umysłów i wartości, rozwijanie umiejętności uczenia się, refleksyjności i kreatywności dziecka. Niezbędna jest do tego edukacja elastyczna, odejście od powielania jednakowych wzorów wymagań i wzorów osobowych, produkcji identycznej wiedzy, a raczej nastawienia na program spersonalizowany, maksymalizujący indywidualne możliwości, ale przy tworzeniu warunków do wspólnego działania, konstruowania znaczeń i rozwijania relacji społecznych itp. Przywołane wartości charakteryzują humanistyczny klimat edukacji dziecka, wskazują także na rozumienie nowych kontekstów i nowych jakości szkolnego uczenia oraz działania na rzecz prawa do równouprawnienia w edukacji i prawa do uznania różnicy, czyli uznania w edukacji dziecka jego indywidualności i prawa do wspólnotowości ${ }^{16}$.

Działania związane $z$ budowaniem przez rodziców i nauczycieli takiej spersonalizowanej przestrzeni edukacyjnej, uwzględniającej konkretne potrzeby i wymagania dziecka, wpisują się we wspomniany powyżej nurt edukacji elastycznej, zindywidualizowanej, otwartej na wspieranie człowieka w jego rozwoju, a nieograniczającej się do kształtowania młodego człowieka według narzuconego odgórnie wzorca.

16 J. Bałachowicz, Edukacja dziecka w okresie przemian kulturowych, w: Kompetencje kluczowe dzieci i mtodzieży. Teoria i badania, red. J. Uszyńska-Jarmoc, M. Bilewicz, Warszawa 2015, s. 20. 
Tworzenie $\mathrm{z}$ wykorzystaniem nowych technologii przyjaznego dziecku i dostosowanego do jego indywidualnych potrzeb środowiska kształcenia wydaje się być istotnym elementem współczesnego podejścia do edukacji, ujmowanej jako proces holistyczny, mający miejsce na pograniczu różnych przestrzeni. Poza tym wyraźnie sprzyja zacieraniu się granic pomiędzy edukacją formalną, ujętą w ramy instytucjonalne, a kształceniem ustawicznym, kładącym nacisk na wielostronny rozwój jednostki i zdobywanie kompetencji kluczowych. Warto podkreślić przy tym, że edukacja wczesnoszkolna stanowi bardzo ważny moment w życiu dziecka, który często decyduje o sukcesach czy porażkach odnoszonych na kolejnych etapach kształcenia. Promowanie u uczniów postaw otwartych, ciekawych świata, nastawionych na zdobywanie nowych umiejętności oraz stopniowe wdrażanie do przejmowania odpowiedzialności za swój osobisty proces uczenia się staje się ważnym zadaniem stojącym wspólnie przed rodzicami i nauczycielami.

\section{Bibliografia}

Bałachowicz J., Edukacja dziecka w okresie przemian kulturowych, w: Kompetencje kluczowe dzieci i mtodzieży. Teoria i badania, red. J. Uszyńska-Jarmoc, M. Bilewicz, Wydawnictwo Akademickie „Żak”, Warszawa 2015, s. 13-37.

Banyard P.E., Underwood J., Understanding the Learning Space (4.07.2008). Elearningpapers, <https://dialnet.unirioja.es/servlet/articulo?codigo= 2937422> [dostęp: 7.10.2016].

Dudel B., Głoskowska-Sołdatow M., Wspótczesna przestrzeń edukacyjna uczniów klas mtodszych, w: Wielowymiarowość przestrzeni życia wspótczesnego dziecka, red. J. Izdebska, J. Szymanowska, Trans Humana Wydawnictwo Uniwersyteckie, Białystok 2009, s. 171-182.

Juszczyk S., Dydaktyka informatyki i technologii informacyjnej, Wydawnictwo Adam Marszałek, Toruń 2006.

Kamińska J., Ocenianie osiagnięć uczniów wedukacji wczesnoszkolnej, Wydawnictwo Harmonia, Gdańsk 2000.

Kupisiewicz C., Kupisiewicz M., Stownik pedagogiczny, Wydawnictwo Naukowe PWN, Warszawa 2009.

Nalaskowski A., Przestrzenie i miejsca szkoty, Oficyna Wydawnicza „Impuls”, Kraków 2002.

Personal Learning Environments, <http://horizon.wiki.nmc.org/Personal+Learning+Environments> [dostęp: 4.10.2016].

Personal Learning Environments. NMC Horizon Report: 2012 K-12 Edition, <http://www.nmc.org/pdf/2012-horizon-k12-ple.pdf> [dostęp: 4.10.2016]. 
Peszko P., Co to jest fipped classroom? Jak dziata odwrócona klasa?, <http:// blog.2edu.p1/2011/09/flipped-classroom-odwrocona-klasa-czyli.html> [dostęp: 11.10.2016].

Podstawa programowa kształcenia ogólnego dla szkół podstawowych, Dz.U. 2016, poz. 895, Załącznik nr 2.

Pulak I., Projektowanie spersonalizowanego środowiska ksztatcenia jako element information literacy, „Bibliotheca Nostra. Śląski Kwartalnik Naukowy” 2012, nr 2(28), s. 87-99, <http://www.sbc.org.pl/dlibra/docmetadata?i $\mathrm{d}=61361 \&$ from=publication $>$ [dostęp: 4.10.2016].

Rafal-Łuniewska J., Indywidualizacja nauczania a edukacja wczesnoszkolna, <https:/www.ore.edu.pl/materiay-do-pobrania-41018/category/244-specyficzne-trudnoci-w-uczeniu-si?download=2846:indywidualizacja-nauczania-a-edukacja-wczesnoszkolna> [dostęp: 5.10.2016].

Sterna D., Ocenianie ksztattujące w praktyce, Wydawnictwo CEO, Warszawa 2006.

Strategia wyprzedzająca tradycyjnq lekcje, Edukacja. Internet. Dialog, <http:// edukacjaidialog.pl/news/strategia_wyprzedzajaca_tradycyjna_lekcje,1966.html> [dostęp: 10.10.2016].

\section{ADRES DO KORESPONDENCJI:}

Dr Irena Pulak

Akademia Ignatianum w Krakowie

Wydział Pedagogiczny

Instytut Nauk o Wychowaniu

e-mail: irena.pulak@ignatianum.edu.pl

Dr Katarzyna Szewczuk

Akademia Ignatianum w Krakowie

Wydział Pedagogiczny

Instytut Nauk o Wychowaniu

e-mail: katarzyna.szewczuk@ignatianum.edu.pl 